University of Nebraska - Lincoln

DigitalCommons@University of Nebraska - Lincoln

Publications from USDA-ARS / UNL Faculty

U.S. Department of Agriculture: Agricultural

Research Service, Lincoln, Nebraska

2005

From Metchnikoff to Monsanto and beyond: The path of microbial control

Jeffrey C. Lord

USDA

Follow this and additional works at: https://digitalcommons.unl.edu/usdaarsfacpub

Part of the Agricultural Science Commons

Lord, Jeffrey C., "From Metchnikoff to Monsanto and beyond: The path of microbial control" (2005).

Publications from USDA-ARS / UNL Faculty. 363.

https://digitalcommons.unl.edu/usdaarsfacpub/363

This Article is brought to you for free and open access by the U.S. Department of Agriculture: Agricultural Research Service, Lincoln, Nebraska at DigitalCommons@University of Nebraska - Lincoln. It has been accepted for inclusion in Publications from USDA-ARS / UNL Faculty by an authorized administrator of DigitalCommons@University of Nebraska - Lincoln. 


\title{
From Metchnikoff to Monsanto and beyond: The path of microbial control
}

\author{
Jeffrey C. Lord * \\ Grain Marketing and Production Research Center, USDA, ARS, 1515 College Avenue, Manhattan, KS 66502, USA
}

Received 15 March 2005; accepted 11 April 2005

\begin{abstract}
In 125 years since Metchnikoff proposed the use of Metarhizium anisopliae to control the wheat cockchafer and brought about the first field trials, microbial control has progressed from the application of naturalists' observations to biotechnology and precision delivery. This review highlights major milestones in its evolution and presents a perspective on its current direction. Fungal pathogens, the most eye-catching agents, dominated the early period, but major mycological control efforts for chinch bugs and citrus pests in the US had questionable success, and interest waned. The discoveries of Bacillus popilliae and Bacillus thuringiensis began the era of practical and commercially viable microbial control. A program to control the Japanese beetle in the US led to the discovery of both $B$. popilliae and Steinernema glaseri, the first nematode used as a microbial control agent. Viral insect control became practical in the latter half of the 20th century, and the first registration was obtained with the Heliothis nuclear polyhedrosis virus in 1975 . Now strategies are shifting for microbial control. While Bt transgenic crops are now planted on millions of hectares, the successes of more narrowly defined microbial control are mainly in small niches. Commercial enthusiasm for traditional microbial control agents has been unsteady in recent years. The prospects of microbial insecticide use on vast areas of major crops are now viewed more realistically. Regulatory constraints, activist resistance, benign and efficacious chemicals, and limited research funding all drive changes in focus. Emphasis is shifting to monitoring, conservation, integration with chemical pesticides, and selection of favorable venues such as organic agriculture and countries that have low costs, mild regulatory climates, modest chemical inputs, and small scale farming.

Published by Elsevier Inc.
\end{abstract}

Keywords: Biological control; Microbial pesticides; Bacillus thuringiensis; Baculoviridae entomogenous fungi; Steinernema; History

\section{Introduction}

Microbial control has followed a meandering path from its inspiration in observations on diseases of beneficial insects to the current work in genetic manipulation. The approach has been applied to weeds and invertebrates other than insects, but its past and present is predominantly in insect control, which is subject of this discussion. Various aspects of the history of microbial insect control have been admirably reviewed by several

\footnotetext{
${ }^{*}$ Fax: +1 7855375584 .

E-mail address: lord@gmprc.ksu.edu.
}

authors (Lacey et al., 2001; Starnes et al., 1993), but the early events are captured most completely by Steinhaus (1949, 1956, 1957, 1975).

Experimental studies in insect pathology began with domesticated insects, the honey bee and the silk worm, most notably with the work of Agostino Bassi and Louis Pasteur. The idea of using diseases to combat pest insects must have grown out of the gradual recognition that they were contagious, passing from diseased to healthy insects under both laboratory and natural conditions, and that the mortality that occurred in natural epizootics could contribute to the control of pest species. Bassi not only artificially transmitted Beauveria bassiana to silkworms and other species but also stated that he could 
do so at will. That statement, made in 1835 , can be judged to be the seminal declaration of microbial control. Based on his observations that the hemolymph of rotting larvae was toxic for healthy larvae, he suggested the use of infusions of rotting eggs to control caterpillars, thereby obliquely suggesting the use of microbes (Steinhaus, 1975).

While the seeds of combating pests with disease lie in the observations and experiments of Bassi and others from the early 19 th century, apparently the first formal, published proposal of microbial control did not appear until 1874 when John LeConte included the approach in his sweeping recommendations for the overhaul of economic entomology in the United States (LeConte, 1874). About that time, Pasteur suggested that pebrine (microsporidia) be applied for control of grape phylloxera but did not act on the idea. In the US, several entomologists led by Hagen made fruitless attempts at the use of commercial yeast to control several insect pests (Steinhaus, 1957).

\section{The Russian beginnings}

While the Americans were experimenting with yeast, the great Russian microbiologist, Elie Metchnikoff (Fig. 1), who was later to win a Nobel Prize for his work on phagocytosis, turned his attention to the grain beetle, Anisoplia austriaca, that was causing great economic loss to Russian cereal crops (reviewed in McCoy et al., 1988; Steinhaus, 1956, 1975). His observation that the beetle's population cycles corresponded to disease outbreaks led him to search for pathogens near Odessa in the Ukraine, where he found several bacteria, a nematode, and a fungus that he referred to as green muscardine and named Entomophthora anisopliae, now known as Metarhizium anisopliae. He suggested that it be applied by dispersing conidia collected in beetle-infested fields, fungus-killed cadavers, and the soil from epizootic locales. Notably, he recommended that fungus production facilities be established to produce inoculum for dissemination to initiate epizootics. He even made the far-sighted suggestion that
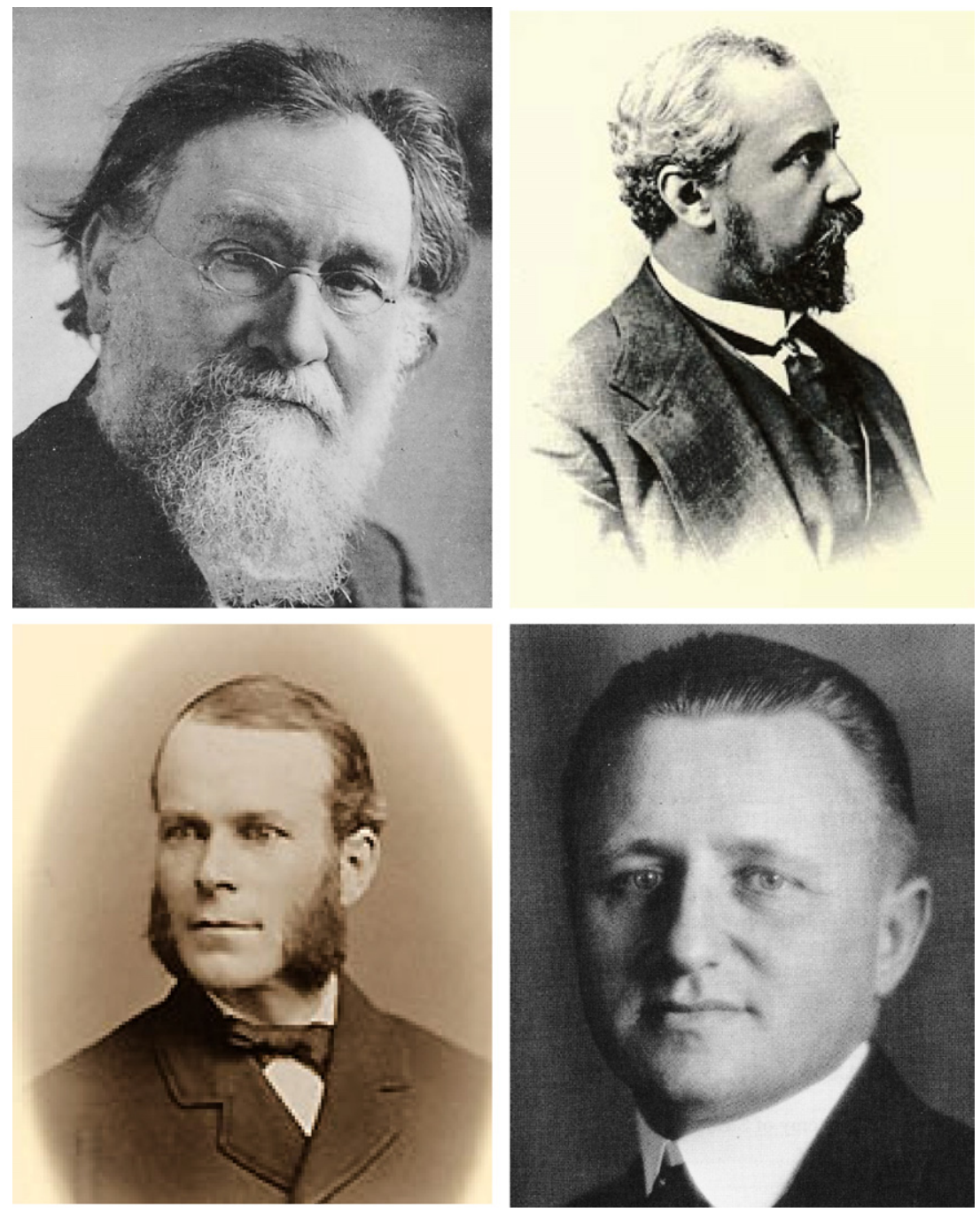

Fig. 1. The early visionaries clockwise from top left: Elie Metchnikoff, John LeConte, Rudolf Glaser, and Francis Snow. 
laboratory manipulations might be made to improve virulence. Efforts toward those goals have persisted to this day. After finding $M$. anisopliae in other regions of Russia and in the sugar beet curculio, Cleonus punctiventris, for which he estimated 40\% mortality (Metchnikoff, 1880), he instigated practical investigations by entomological commissions in Kharkov and Odessa. In seeking propagation methods, he discovered that conidia could be produced economically on sterilized brewer's mash. According to a biography by his widow (Metchnikoff, 1921), Metchnikoff initiated field experiments on the land of a wealthy baron before turning his attention to other matters and handing the work over to a young entomologist. However, the trials are not confirmed by other sources (Steinhaus, 1975), and credit for the first field trials generally goes to his protégé, Isaak Krassilstschik.

Following the Metchnikoff's lead, Krassilstschik established a production plant in Smela that had an output of $55 \mathrm{~kg}$ of $M$. anisopliae conidia in the first 4 months of operation using beer mash as the substrate. The conidia were mixed with sand and scattered on fields around Kiev. Mortality of $55-80 \%$ of C. punctiventris was reported, but the work was discontinued. Opinions vary as to whether this was because of cessation of sugar beet production or inconsistent results (Steinhaus, 1956). Regardless of the termination of their work, Metchnikoff and Krassilstschik inspired many Europeans to attempt or recommend the use of fungi to control insect pests. Krassilstschik (1888) with his mentor's inspiration can be credited with the first industrial scale production of a microbial pesticide and the first field application. Following the Russian lead, Europeans tested fungi on grasshoppers, flies, forest moths, chafers, and other insects, but the most ambitious work was taking place across the Atlantic.

\section{Snowing conidia in the US plains}

At the end of the 19th century on the Midwest plains of the US, one of the largest, most prominent, and least understood group of programs in microbial control was creating interest in microbial control. Perhaps, the most extensive application of microbial control in the early years was the treatment of chinch bugs, Blissus leucopterus in the US Midwest with Be. bassiana. A white fungus had been reported on Midwestern chinch bugs as early as 1867 , and the first attempt to initiate an epizootic by disseminating the fungus was made by Lugger who scattered diseased insects in Minnesota fields in 1888 (Lugger, 1888). The attempt appeared successful, but Lugger suspected that the fungus was already present and he had only reintroduced it. In the same year, Francis H. Snow, who was a one-man mathematics and science faculty at the University of Kansas at its founding and later its chancellor, began his program of fungus introductions. In spite of his workload, he vigorously pursued an interest in applied entomology. His efforts led the Kansas legislature to establish an experiment station at the University of Kansas to produce Be. bassiana conidia to be distributed to farmers without charge. Almost 50,000 packages were distributed in Kansas. Seven neighboring states initiated their own programs. The approaches varied. In Nebraska, for example, growers exchanged live chinch bugs for infected cadavers to be distributed. In the early years, observers' reports were favorable, but enthusiasm waned and the last of the programs was terminated in the early 1900s. A comprehensive appraisal of the Kansas program by the United States Department of Agriculture (USDA) found that the natural occurrence of fungus-infected chinch bugs was so great and widespread that the introductions had no measurable impact (Billings and Glenn, 1911). They also concluded that where the fungus was not evident, it was because conditions were unfavorable. Whether or not the applications were successful, Snow must be credited with alerting farmers and entomologists to the potential of epizootics to control insect pests. Steinhaus (1949) urges caution in extending the conclusions of Billings and Glenn beyond this case.

\section{Fungus friends}

Over the following decades, a story similar to the $B e$. bassiana experience on the US plains unfolded in Florida with the "friendly fungi." The widespread occurrence of fungi on scale insects (Coccidae) and whiteflies (Aleyrodidae) that were pests of citrus was attracting the attention of growers and entomologists (Fawcett, 1944; Fisher, 1947, 1950; McCoy, 1978; McCoy et al., 1988; Steinhaus, 1975). A complex of fungal genera were involved, most notably Aschersonia, Agerata, Verticillium, Sphaerostilbe, Podonectria, Myriangium, and Hirsutella. Once again, opinions differed on the real impact that the fungi had, and efforts at human intervention to augment natural control were desultory. Some workers were convinced that pest mortality could be markedly increased if fungal sprays were applied during the damp summers. Others contended that the fungi were not a reliable alternative to chemical treatments. Fawcett (1944) suggested that differences in results from applications may have been due to whether or not the naturally occurring conidia concentrations were at the saturation point for infections at the time of application.

Fawcett, a plant pathologist who dabbled in insect mycology throughout his career, developed culture methods for Aschersonia and Agerata species in the early 1900 s, giving impetus to inoculative releases. The Florida State Experiment Station distributed fungi for whiteflies with a nominal fee of 75 cents to cover the cost, and 
private enterprises offered the fungi for sale. The fungi of scale insects were not commercially available, and growers usually obtained them from nearby groves. Efforts were also made to market fungi to citrus producers in California, but the results were generally poor. Steinhaus (1975) attributed the failure of similar attempts to use fungi in California to lower moisture during the months when temperature was adequate for fungal development. Fawcett (1944) noted that the full benefit from the friendly fungi may not have been perceived because insect mortality due to fungus is not made obvious by conidiation on the cadavers unless they are exposed to high moisture, an astute observation that eludes too many today.

To this day, it is not clear just how friendly the friendly fungi really were (Fisher, 1947), but at least in the case of Aschersonia, the benefit carried forth in Florida (McCoy, 1978) and elsewhere. Several Aschersonia species were introduced into the former Soviet Union from Asia, Cuba, and the United States between 1958 and 1973 for biological control of the citrus whitefly Dialeurodes citri, which had been accidentally imported and lacked indigenous natural enemies (McCoy et al., 1988). Aschersonia aleyrodis and Aschersonia placenta were spread through application and natural dispersal in the Black Sea region with reportedly great effect.

Fungi were the agents used in the preponderance of early work in microbial control and virtually all of it in the 19th and early 20th century. This is understandable because they are the most visible of insect diseases, and most are readily culturable. An unfortunate consequence of this fact is that the positive and negative experiences with entomogenous fungi affected the approach to all microbial control.

\section{The rise of bacteria}

d'Herelle $(1911,1912,1914)$ is credited with the first recognition of a bacterial epizootic in insects and the first attempt to use them in applied microbial control. He observed epizootics in Mexican populations of the grasshopper Schistocerca americana of a bacterium that he isolated and designated Coccobacillus acridiorum. He applied the bacterium in several Latin American countries with reportedly positive results in some places and not in others. The identity and efficacy of the bacterium have been questioned (Bucher, 1959), but the approach was followed with enormous success.

Bacteria in microbial control became a reality with appreciation of the potential of Bacillus popilliae (Fig. 2). The introduction of the Japanese beetle, Popillia japonica, into the US in 1916 provided the impetus for the establishment of a USDA laboratory and a program to retard its spread. Two of the most significant events of
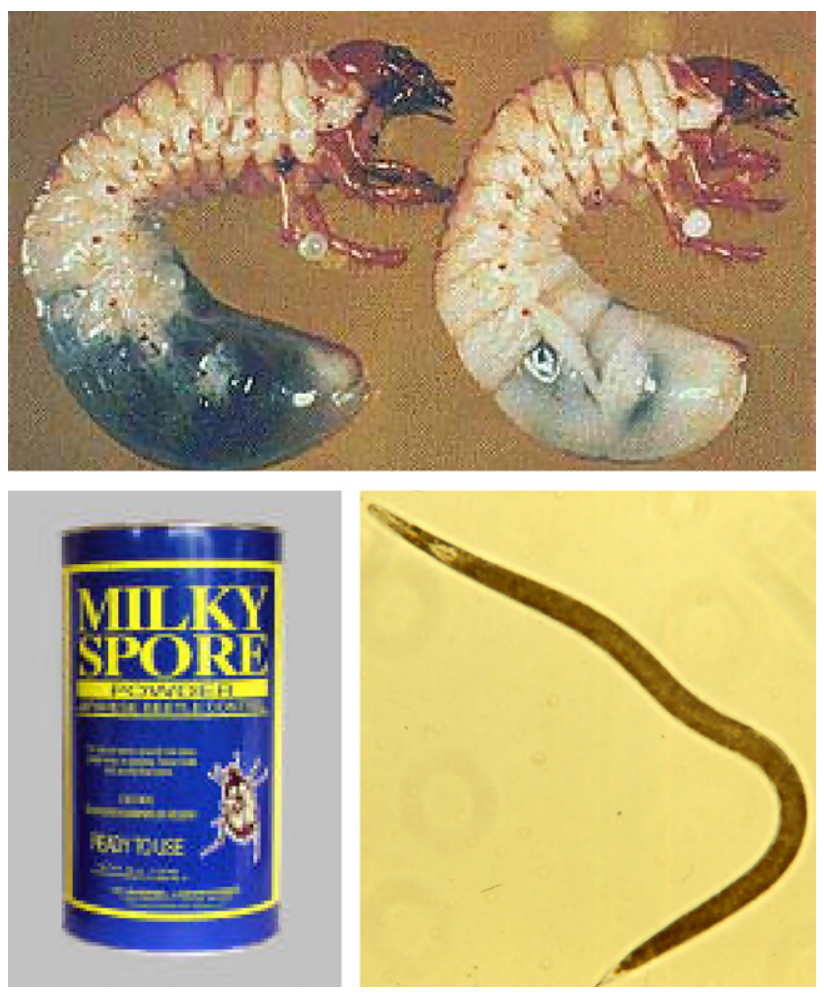

Fig. 2. The Japanese beetle and its diseases, a source of inspiration. Top: healthy grub and grub with milky spore disease, seen in hemolymph droplet (Michael Klein). Bottom left: commercial B. popilliae. Bottom right: S. glaseri (James Campbell).

microbial control (Table 1) resulted from this program. One was the discovery of Steinernema glaseri and the beginning of microbial control with nematodes. The other, the discovery of $B$. popilliae and its application for control of the Japanese beetle, was the first well-recognized case of the use of bacteria for insect control (Steinhaus, 1975; Vail et al., 2001).

\section{Table 1}

Major events in the progress of microbial pest control

1873 LeConte makes first formal proposal for microbial insect control 1879-1884 Metchnikoff and Krassilstschik experiment with $M$.

anisopliae, establish the first operational production plant for a microbial control agent and apply to control sugar beet curculio in the Ukraine

1888-1902 Be. bassiana applications for chinch bug in US Midwest 1906-1942 "Friendly fungi" in Florida

1911 B. thuringiensis was first identified when it was discovered that it

killed the larvae of flour moths

1921-1940 Development of B. popilliae

1929 Glaser and Fox discover $S$. glaseri

1938 Sporéine $(\mathrm{Bt})$, the first commercial product

1958 1st international conference on insect pathology in Prague

1959 Journal of Insect Pathology

1964 Oryctes virus program begins in South Pacific

1975 Heliothis NPV registration

1977 Goldberg and Margalit report the discovery of B. thuringiensis subsp. israelensis

$1995 \mathrm{Bt}$ transgenic corn registration 
The discovery was an incremental process involving several individuals. In 1921, Smith and Hadley recognized an unknown microbial disease in Japanese beetle grubs. Five years later, Spencer isolated unidentified bacteria with which he infected healthy grubs. Some of the bacteria proved highly pathogenic. In 1933, White and Hawley divided the bacteria into two groups, black and white. The three in the black group were all culturable. The bacteria of the white group were often found in the field in grubs with an unnatural milky appearance, but could not be cultured. Later, Hadley concluded, and White and Dutky confirmed, that the white group comprised two distinct organisms (White and Dutky, 1940). Dukty named them B. popilliae and Bacillus lentimorbis. State and federal agencies developed and patented methods for the mass propagation of $B$. popilliae in vivo, culture on artificial medium not having succeeded to this day. By the mid-1940s, commercially viable spore dusts could be prepared, and only recently with the closing of Fairfax Laboratories did B. popilliae cease to be available for purchase.

\section{Bacillus thuringiensis changes the paradigm}

By almost any standard, B. thuringiensis (Bt) in all its strains and extractions is the grand success of microbial control. Briggs (1986), Beegle and Yamamoto (1992), and Federici (this volume) review its history from discovery through reduction to toxin genes for transformation of plants. Only some highlights in applied aspects are noted here.

After its discovery in diseased silk worms by Ishiwata in 1901 and Berliner's 1911 description based on an isolate from diseased Mediterranean flour moth Ephestia kuehniella found in the state of Thuringia, Germany, there was little activity until Mattes obtained a new isolate that was to become the basis for early microbial control attempts and commercial products. The first recorded trials of $\mathrm{Bt}$ for insect control were conducted in Hungary in the 1920s and Yugoslavia in the early 1930s to control the European corn borer, Ostrinia nubilalis (Beegle and Yamamoto, 1992). Promise shown in the trials led to the first commercial production by Laboratoire Libec in France. The product, Sporeine, was available in 1938, but it was unfortunately short-lived due to World War II.

In the early 1950 s, Steinhaus began to experiment with Bt. He met with Fisher, Director of Research and Development at Pacific Yeast Products (later Bioferm) of Wasco, California in 1956. Together they convinced the company's president to produce Bt, and the product Thuricide was soon available (Steinhaus, 1975). The name Thuricide has survived the maze of industrial transformations and is a product of Valent BioSciences today. Not long after Bioferm introduced its Bt product, Nutrilite Products entered the market with its product, Biotrol. Over the ensuing years many companies all over the world have been in and out of the $\mathrm{Bt}$ business. As recounted by Beegle and Yamamoto (1992), the early products had various problems. Standardization was based on spore count rather than potency, the products often contained the heat-tolerant exotoxin, and most were based on variety thuringiensis and of low potency. In France in 1962, Edouard Kurstak isolated another variety from E. kuehniella, the host of Berliner's isolate. Howard Dulmage obtained a similar isolate, designated HD-1, from diseased Pectinophora gossypiella. Kurstak's and Dulmage's isolates were serotyped by de Barjac and Lemille (1970) and designated variety kurstaki. HD-1 became the basis for products that were competitive with chemical insecticides in performance and cost, and before long all of the B. thuringiensis companies that produced $\mathrm{Bt}$ were producing variety kurstaki. It remains by far the greatest commercial success of microbial control, in the strict sense. Much of Bt's commercial success prior to the introduction of transgenic plants was in forestry. According to Burges and Daoust (1986), its use against the spruce budworm and gypsy moth in North American forests accounts for $60 \%$ or more of world sales. But other varieties, such as the Coleoptera-active $B$. thuringiensis var. tenebrionis, discovered by Krieg et al. (1983), have also had great impacts.

In addition to the prominent position that $\mathrm{Bt}$ and its genes have taken in agriculture and forestry, $B$. thuringiensis subsp. israelensis (Bti), first found in the Negev Desert (Goldberg and Margalit, 1977) has come to be used extensively for the control of larvae of pest and vector black flies and mosquitoes around the world, providing both medical and environmental benefit (Lacey and Undeen, 1986). An outstanding success in cooperation between industry and a governmental organization to achieve those benefits is the World Health Organization's Onchocerciasis Control Programme wherein Bti applications comprise up to $50 \%$ of all insecticide applications (Guillet et al., 1990).

A problematic milestone in the Bt story was the observation that resistance developed in the storedproduct pest Plodia interpunctella (McGaughey, 1985). The resistant moths were from a native population in a grain storage facility that had been treated in an efficacy field trial. Field resistance was soon reported in the diamondback moth Plutella xylostella (Tabashnik et al., 1990), and resistance management has been a major component of use strategies since.

In recent years, the advent of transgenic plants with $\mathrm{Bt}$ toxin genes has been revolutionizing agriculture. For the story of Bt transgenics, see the article by Federici in this volume. 


\section{Steinernema glaseri}

In 1929, Glaser and Fox were investigating Japanese beetle grub mortality, on a golf course in New Jersey when they discovered that many were parasitized by a nematode (Glaser and Fox, 1930). Later, the nematode was characterized and named Neoaplectana glaseri by Steiner, nematology specialist of the USDA. In surveys of hundreds of additional locations in New Jersey and Pennsylvania, Glaser and his colleagues did not find the parasite to be present (Glaser et al., 1940). In view of the possibilities for culturing and disseminating large numbers of nematodes, Glaser, a parasitologist at the Rockefeller Institute for Medical Research, was retained as a consultant and began work on its artificial culture, a daunting prospect since no parasitic nematode had previously reproduced in artificial media in spite of many attempts by parasitologists. After much preliminary work, Glaser and McCoy were successful in culturing the nematode (McCoy and Glaser, 1936). Then, many laboratory and field experiments were made to determine dosages, survival, extent of parasitism, etc. Experimental work was continued from 1931 to 1938, for many practical difficulties had to be resolved before a colonization program could be developed. Various methods of introduction, such as a water suspension of the nematodes, burying small samples of culture every few yards, and spraying the nematodes on the soil surface, were tried. In 1935, field introductions were made in 10 locations in New Jersey with parasitized grubs being recovered later from the treated areas. In the next year, subsurface applications were made in 41 fields with a total area of more than $40,000 \mathrm{~m}^{2}$, and sizable declines in the grub population were noted in treated fields (Glaser et al., 1940). The successful initial introductions led to a statewide colonization program started in 1939. At the same time, through the cooperation of the Federal Japanese Beetle Laboratory at Moorestown, New Jersey, colonies of the bacterial disease then known as Type A, $B$. popilliae, were introduced. Nematode releases were made at 563 locations at 5.6-mile intervals across the beetleinfested areas of New Jersey. Glaser et al. (1940) believed that the introductions resulted in rapid spread. No systematic assessment of the introductions was made until 1991 when Gaugler et al. (1992) determined that the introductions were unsuccessful, probably due to inhibition of the symbiotic bacteria by anti-microbial compounds that were used in mass rearing the nematodes. In spite of the problems with the larger program, the preliminary colonization experiments by Glaser and Farrell (1935) validated the strategy, and S. glaseri remains a viable agent for inoculative release.

Steinernema glaseri is no longer commercially available, but it paved the way for numerous nematode products. They are often the products of small companies and are likely to continue to be as long as they are exempt from the costs and constraints imposed by government regulation.

\section{Viruses}

Insect baculoviruses are particularly attractive as bioinsecticides because of two factors. They are safe for vertebrates and other non-target fauna, and they are generally highly pathogenic, host death being the most likely outcome of an infection. Baculovirus control of pest insect populations was demonstrated in the 1940s, but the first registered commercial product did not appear for another 30 years. This was the Helicoverpa zea nuclear polyhedrosis virus (NPV) registered under the tradenames Viron/H and later Elcar. Like Bt, these products began with Bioferm, where production was guided by Carlo Ignoffo, who joined the company in 1966 (Steinhaus, 1975). Registration was granted in 1973 to International Minerals and Chemical Corporation after 9 years of work and safety testing (Falcon, 1976). Since then, a number of baculovirus insecticides have been registered and produced commercially. They are all wild-type baculoviruses and, like most microbial insecticides, have had limited success for various reasons. Not the least of these reasons is the length of time that is needed to achieve pest population suppression. The advent of transgenic viruses was seen as a way to improve potency and speed. The first field trials with a benignly marked transgenic baculovirus took place between 1986 and 1989, and the first field trial of a transgenic viral insecticide was in 1993 in the United Kingdom (Cory et al., 1994). In spite of the improved efficacy, no recombinant baculovirus insecticide has yet been registered for commercial use or applied experimentally over large areas.

While viral insecticides continue to be viable insect control products, classical biological control by introduction has been an approach for viral control that has had some of the most enduring successes. Forestry has been the venue of some of the major successes of microbial control with viruses by both inoculative introduction and inundative application. Sawflies, in particular, have been major targets, and the NPV of the European pine sawfly, Neodiprion sertifer, is the most widely tested and operationally used sawfly baculovirus (Cunningham and Entwistle, 1981). N. sertifer was discovered in North America in 1925 after introduction from Europe, and populations built up apparently unimpeded by viral disease. Viruses were known in Europe, and diseased larvae were sent from Sweden to Ontario in 1949. An NPV that was isolated from them proved to be very efficacious when applied to the field (Bird, 1961; Bird and Whalen, 1953). According to Bird (1961), in contrast to other sawfly NPV such as that of Neodiprion lecontei, applications result in slow spread of the disease, but the spread 
is greatly accelerated by the presence of parasitoids that act as the chief agents of transmission from tree to tree. $N$. sertifer NPV was used across Europe and in North America for forestry, Christmas tree production, and other private uses until around 1970 when governments began to consider requiring virus registrations. After registrations were obtained in the 1980s, its use has resumed.

A well-documented (Bedford, 1980, 1981, 1986) and highly successful virus introduction for microbial control took place in the Pacific and Indian Ocean islands and Southeast Asia, where the rhinoceros beetles Oryctes rhinoceros and Oryctes monocerus are serious pests of coconut and other economically important palms. $O$. rhinoceros in particular had spread from the Asian mainland to many Pacific islands. The limited cultural and chemical controls available were ineffective. In 1963, Huger (1966) found a beetle-specific virus from Malaysia (initially named Rhabdionvirus oryctes and now referred to as Oryctes virus unclassified). The discovery led to a program of production and release via autoinoculation traps that spread the virus within and among beetle populations on coconut plantations and other venues. The program was tailored to the particular hostpathogen relationship. Conventional, inundative foliar applications are ineffective, since the beetle dwells inside rotting stumps, standing palms, and rubbish piles, or tunnels inside young coconut leaves. But a classical biological control approach has resulted in significant longterm control with reductions below economic thresholds in many locations (Zelazny et al., 1992).

Unlike the occluded baculoviruses, the Oryctes virus infects adults, as well as larvae. In adults, the virus multiples in cells of the midgut epithelium, resulting in gradual disintegration of the gut, and a severe diarrhea which produces virus-contaminated feces. The insect ultimately dies, but it may take up to 30 days for mortality to occur, during which time it is capable of flying and mating. Thus, the infected adults disseminate the virus in two ways. First, the virus-laden feces contaminate feeding, mating, and breeding habitats in palm logs and stumps. Second, the virus is transmitted during mating (Zelazny, 1976).

For introductions and augmentation, live adult beetles are captured, orally inoculated with a virus suspension, and released back into the environment. During the 1970s, this procedure was carried out in at least 10 Pacific and Indian Ocean nations. Releases consistently resulted in infection rates around $40 \%$, with similar or greater rates of population decrease recorded over multiple years. The establishment of the virus has significantly reduced beetle damage on most of the islands where it was introduced with little or no expenditure (Huber, 1986).

Where there had been no previously effective controls, the establishment of the Oryctes virus had a dramatic and visible effect on the beetle population. The $40 \%$ control that was achieved is a great improvement over the prior situation. Effective recycling of the virus made additional labor or financial inputs unnecessary, making the program low-input and practical. The public benefited by increased coconut yields, achieved without the use of toxic pesticides. With the virus having no potential as a commercial product, public funding was a necessity. Fortunately, the project was funded for many years by aid organizations including the United Nations, the South Pacific Commission, and several bilateral foreign aid programs (Huber, 1986).

\section{Recent successes}

Microbial control has evolved as we have developed a better understanding of the pathogens, their hosts, and their environments. We are learning what is practical and what is not. The following are selected examples of ongoing programs that offer lessons in for future successes.

\section{Control of Pine Moth with Be. bassiana}

The application of Be. bassiana for pine moth caterpillars, Dendrolimus spp., in the People's Republic of China, probably represents the largest use of a biocontrol agent. It illustrates several of the features that exemplify a currently successful microbial control program. There is a key pest rather than a complex with some components for which the fungus may not be effective. In forestry, tolerance for pest infestation is much greater than in most agricultural systems. There are large and diverse research and application communities that have had years of sustained effort that was not impeded by commercial profit demands.

The programs began in the 1950s and expanded in the 1960s when they benefited from a low-cost labor pool that allowed initial production and application without a large capital investment. The early conidia production was in pits and baskets where contamination was minimized by heavy inoculation. Since then, the production has evolved into sophisticated closed systems. In 1980, there were 60 factories in Hunan Province alone, and $85 \%$ of the biological control efforts were with Be. bassiana (McFadden et al., 1981). At least one million hectares of pine forests are now involved. The fungus is locally propagated, cheaply, on a bran or peat substrate, and is applied by air or ground equipment, as a spray or dust. Initially, during the 1970 s, 'mortar bombs' containing firecrackers were used for dispersal of the fungus to control the pine moth in tall trees on plantations. The technique proved to be effective, but was abandoned in the 1980s because the price of firecrackers made it too 
expensive to use and the regulation of such goods as firecrackers and fireworks became stricter. It was also a potentially dangerous means of dispersing the fungus even though there were no reports of accidents involving this method. Applications are usually only needed at 3 year intervals ( $\mathrm{Z}$. Li, personal communication).

\section{Entomophthorales and field propagation}

Inoculative introductions, i.e., the use of microbes as classical biological control agents, have been a matter of serendipity as much as science. Unfortunately, planned introductions have become difficult as regulatory restrictions have become increasingly onerous. There are several cases of successful introductions of pathogens that are of uncertain or unintentional release. The fungus, Entomophaga maimaiga, is such a case. It was introduced into the US from Japan in 1910 and 1911 and again in 1985 and 1986 (Soper et al., 1988) to control the gypsy moth, Lymantria dispar. But it was not recovered from these sites. In 1989, E. maimaiga epizootics were reported in several New England states, but their source remains a mystery (Hajek et al., 1995; Weseloh, 1998). With some human intervention in advancing its distribution, E. maimaiga has spread throughout the range of the gypsy moth in North America and caused numerous epizootics. It is generally acknowledged that E. maimaiga is probably responsible for the decline of gypsy moth infestations, and it is expected to continue its spread and pest suppression as the moth advances into new areas.

The Entomophthorales lend themselves to an approach that is little used in microbial control, conservation. By allowing natural controls to take effect, wasteful pesticide application can be avoided. A current program of conservation of the entomophthoralean pathogen, Neozygites fresenii, has been highly successful in saving time and money for cotton growers in the Southeastern US. The cotton aphid, Aphis gossypii, is the object of a scouting program that was developed to avoid pesticide applications when they are unnecessary and disruptive of the complex of natural controls (Hollingsworth et al., 1995). The Internet is used to inform growers of the program (http://www.uark.edu/misc/ aphid/). The service is funded by a grower group, Cotton Incorporated, and the University of Arkansas to help cotton growers reduce input costs by reducing applications of insecticide for aphid control when the fungus is active and can provide adequate control on its own without the loss of beneficial species, resistance development, coverage problems, and resurgence associated with chemical control.

In 1990, Donald Steinkraus identified N. fresenii as the fungus that rapidly reduced cotton aphid populations to low levels in Arkansas and other southern states. His team found that they could accurately diagnose the percentage of infected aphids in cotton fields and predict when aphid populations would crash due to the fungus. Based on this information a sampling service began in 1993 with the cooperation of extension and IPM specialists in several states. A cooperator, who may be a grower, consultant, extension agent or researcher, receives a sampling kit at no cost. When cotton aphidinfested fields are encountered, the cooperator collects aphids and sends them back to the laboratory for preparation and diagnosis. The results are faxed back to the cooperator and posted on the Internet. When results indicate that $15 \%$ of aphids sampled in a field are infected with the fungus, it is likely that the infection rate will increase. When $30-90 \%$ of the aphids are infected with the fungus, the aphid population will decline. In both of these cases, the grower can usually save money by not applying a chemical for aphid control.

The recent successes listed above all have in common that non-profit organizations are responsible for the programs. Other such cases include the highly successful control of Anticarsia gemmatalis in Brazil with NPV (Moscardi, 1999) and the use of NPVs for sawflies (Cunningham and Entwistle, 1981). Many microbial control strategies are dependent on industrial participation to register and produce the agents and put them in the hands of end users. The profit motive and corporate culture determine how this is done.

\section{The experience with mycoinsecticides in the US}

Industrial experience with Be. bassiana and M. anisopliae can serve as an illustration of how difficult and complex the commercialization of microbial control agents can be. In the 1990s, three small US companies that were backed by venture capital obtained registrations of the two species that were used in the first efforts at microbial control. None of these companies achieved its projected revenue stream, and their products have been removed from the market or the business has been sold to another company that markets almost entirely outside of the US. What went wrong? There were many unforeseen or under-appreciated problems. Competition with the new safe and efficacious chemical pesticides is particularly difficult. For example, the use of Be. bassiana to control whiteflies and thrips in greenhouses and nurseries dropped off quickly when efficacious chemicals with short re-entry intervals were introduced. A core problem was the basic conflict between the business aspects and the technical aspects. There is inevitable pressure to concentrate on large markets. Business managers are most interested in the major crops such as corn, cotton, and soybeans. With the special exception of transgenic plants, it is especially difficult for microbial control agents to compete in such areas where mechanized agriculture and low-cost inputs are the norm. Busi- 
ness managers are apt to underestimate development time and cost and to overestimate market penetration. When young companies depend on venture capital, there is pressure to generate revenue, sometimes before products are ready. A badly mixing formulation or an inadequate shelf life can cause an end user to lose interest. Failures are not forgotten.

Mycoinsecticides have some fairly exacting requirements for commercial success. There must be some tolerance for damage. Appropriate targets include those where pest damage is indirect, or where low pest populations do not cause economic loss. Organic farming is especially appropriate because there is no competition from synthetic chemicals, some damage is expected, and the growers are willing to make special efforts to use and judge the products correctly. Unfortunately, these specialty uses in the absence of large-scale applications have not been enough for commercial success of any microbial pesticides in the US.

\section{The future}

Reviews of the prospects for microbial control are not always optimistic, and there is little doubt that some of the familiar approaches will fade away. What will drive microbial control in the future? It is apparent that utilization of pathogen genes, especially for toxins, will continue to be a productive major thrust. It is unlikely that before World War II anyone could have foreseen the agricultural revolution that would develop from the implantation of bacterial genes into plants. No doubt, there are useful discoveries to be made as the genomes of less understood pathogens become sequenced and studied. Certainly, the revolution in genetic manipulation will have a profound and unpredictable impact on the future on microbial control.

Certain past trends are likely to continue. Microbial control has had many of its greatest successes where chemical insecticides are not practical or acceptable, such as in forestry. There is an ongoing shift in the venues of inundative applications of mass-producible pathogens that is likely to continue. The less developed countries offer advantages for low-cost production and manual application, which allows the necessary contact delivery. One of the most difficult barriers to commercial microbial pesticides has been the gauntlet of regulations for individual national and regional governments. Less developed nations have less onerous regulatory constraints. In the developed countries, the organic farming movement and anti-chemical sentiment will continue to offer opportunities for microbial control for the foreseeable future.

Several forces are at work that offer encouragement for the future of microbial control. While the progress to date has been gradual, there is promise for improved regulatory harmonization, significantly reducing devel- opment costs. As more is learned about the biology of pathogens, not only can they be used more efficiently, but government regulators will be better able to judge and document pathogen safety. Aside from the regulation of microbial control itself, the current regulatory climate offers an opportunity for pathogens in the loss or restriction of many traditional chemicals.

No doubt, there are unpredicted opportunities for the conservation strategy to enhance natural control. The successful, if unintentional, introductions that have occurred in the past and ever improving detection methods argue for continued pursuit of that approach. In the past, much of the success in classical biological control by introduction of microbes has been due to serendipity. With advances in sampling and detection technology and in our knowledge of pest and natural enemy ecology, selection and implementation of agents and strategies will improve. However, the barriers to importation of beneficial species will have to be made less problematic.

In 125 years since Metchnikoff proposed the use of $M$. anisopliae to control the wheat cockchafer, microbial control has progressed from the application of naturalists' observations to precision delivery and the transfer of microbial genes. There have been and continue to be many and varied obstacles in its path. Enthusiasm has waxed and waned, commercial enterprises have come and gone. But inventive minds continue to devise new approaches for microbial control.

\section{Acknowledgments}

I am grateful to Don Steinkraus and Zengzhi Li for providing information. I thank Drs. Elizabeth Davidson and James Harper for providing the opportunity to prepare this review and their helpful suggestions on an earlier version. Mention of trade names or commercial products in this article is solely for the purpose of providing specific information and does not imply recommendation or endorsement by the US Department of Agriculture.

\section{References}

Bedford, G.O., 1980. Biology, ecology, and control of palm rhinoceros beetles. Annu. Rev. Entomol. 25, 309-339.

Bedford, G.O., 1981. Control of the rhinoceros beetle by baculovirus. In: Burges, H.D. (Ed.), Microbial Control of Insects and Plant Diseases. Academic Press, London, pp. 409-426.

Bedford, G.O., 1986. Biological control of the rhinoceros beetle (Oryctes rhinoceros) in the South Pacific by baculovirus. Agr. Ecosyst. Environ. 15, 141-147.

Beegle, C.C., Yamamoto, T., 1992. History of Bacillus thuringiensis Berliner research and development. Can. Entomol. 124, 587-616.

Billings, F.H., Glenn, P.A., 1911. Results of the artificial use of the white-fungus disease in Kansas. USDA Bur. Entomol. Bull. 107, 58 pp. 
Bird, F.T., 1961. Transmission of some insect viruses with particular reference to ovarial transmission and its importance in the development of epizootics. J. Insect Pathol. 3, 352-380.

Bird, F.T., Whalen, M.M., 1953. A virus disease of the European pine sawfly, Neodiprion sertifer (Geoffr.). Can. Entomol. 85, 433-437.

Briggs, J.D., 1986. Pioneering and advanced phases of commercial use of Bacillus thuringiensis in North America. In: Kreig, A., Huger, A.M. (Eds.), Mitteilungen Aus Der Biologischen Bundesanstalt Für Land- Und Forstwirtschaft Berlin Dahlem, vol. 233. Paul Parcey, Berlin, pp. 25-35.

Bucher, G.E., 1959. The bacterium Coccobacillus acridiorum d'Herelle: its taxonomic position and status as a pathogen of locusts and grasshoppers. J. Insect Pathol. 1, 331-346.

Burges, H.D., Daoust, R.A., 1986. Current status of the use of bacteria as biocontrol agents. In: Samson, R.A., Vlak, J.M., Peters, D. (Eds.), Fundamental and Applied Aspects of Invertebrate Pathology. Foundation of the Fourth International Colloquium of Invertebrate Pathology. Wageningen, The Netherlands, pp. 514-517.

Cory, J.S., Hirst, M.L., Williams, T., Hails, R.S., Goulson, D., Green, B.M., Carty, T.M., Possee, R.D., Cayley, P.J., Bishop, D.H.L., 1994. Field trial of a genetically improved baculovirus insecticide. Nature $370,138-140$

Cunningham, J.C., Entwistle, P.F., 1981. Control of sawflies by baculovirus. In: Burges, H.D. (Ed.), Microbial Control of Pests and Plant Diseases 1970-1980. Academic Press, New York, pp. 379-407.

de Barjac, H., Lemille, F., 1970. Presence of flagellar antigenic subfactors in Serotype 3 of Bacillus thuringiensis. J. Invertebr. Pathol. 15, 139-140.

d'Herelle, F., 1911. Sur une épizootie de nature bactérienne sévissant sur les sauterelles au Mexique. C. R. Acad. Sci. Paris Ser. D 152, 1413-1415.

d'Herelle, F., 1912. Sur la propagation, dans la Républic Argentine, de l'épizootie des sauterelles du Mexique. C. R. Acad. Sci. Paris Ser. D $154,623-625$

d'Herelle, F., 1914. Le coccobacille des sauterelles. Ann. Inst. Pasteur (Paris) 28, 280-328, 387-407.

Falcon, L.A., 1976. Problems associated with the use of arthropod viruses in pest control. Annu. Rev. Entomol. 21, 305-324.

Fawcett, H.S., 1944. Fungus and bacterial diseases of insects as factors in Biological control. Bot. Rev. 10, 327-348.

Fisher, F.E., 1947. Insect disease studies. Ann. Rpt. Florida Agr. Exp. Sta. 162 pp.

Fisher, F.E., 1950. Entomogenous fungi attacking scale insects and mites on citrus in Florida. J. Econ. Entomol. 43, 305-309.

Gaugler, R., Campbell, J.F., Selvan, S., Lewis, E., 1992. Large-scale inoculative releases of the entomopathogen Steinernema glaseri: assessment 50 years later. Biol. Control 2, 181-187.

Glaser, R.W., Farrell, C.C., 1935. Field experiments with the Japanese beetle and its nematode parasite. J. N. Y. Entomol. Soc. 43, 345-371.

Glaser, R.W., Fox, H., 1930. A nematode parasite of the Japanese beetle Popillia japonica (Newm.). Science 71, 16-17.

Glaser, R.W., McCoy, E.E., Girth, H.B., 1940. The biology and economic importance of a nematode parasite in insects. J. Parasitol. 26, 479-495.

Goldberg, L.J., Margalit, J., 1977. A bacterial spore demonstrating rapid larvicidal activity against Anopheles sergentii, Uranotaenia unguiculata, Culex univittatus, Aedes aegypti and Culex pipiens. Mosq. News 37, 355-358.

Guillet, P., Kurtak, D.C., Philippon, B., Meyer, R., 1990. Use of Bacillus thuringiensis israelensis for onchocerciasis control in West Africa. In: de Barjac, H., Sutherland, D.J. (Eds.), Bacterial Control of Mosquitoes and Black Flies: Biochemistry, Genetics and Applications of Bacillus Thuringiensis Israelensis and Bacillus Sphaericus. Rutgers University Press, New Brunswick, pp. 187-201.

Hajek, A.E., Humber, R.A., Elkinton, J.J., 1995. Mysterious origin of Entomophaga maimaiga in North America. Am. Entomol. 41, $31-42$.
Hollingsworth, R.G., Steinkraus, D.C., McNew, R.W., 1995. Sampling to predict fungal epizootics in cotton aphids (Homoptera: Aphididae). Environ. Entomol. 24, 1414-1421.

Huber, J., 1986. Use of baculoviruses in pest management programmes. In: Granados, R.R., Federici, B.A. (Eds.), The Biology of Baculoviruses: Volume II, Practical Application for Insect Control. CRC Press, Boca Raton, pp. 181-202.

Huger, A.M., 1966. A virus disease of the Indian rhinoceros beetle, Oryctes rhinoceros (Linnaeus), caused by a new type of insect virus, Rhabdionvirus oryctes gen. n., sp. n. J. Invertebr. Pathol. 8, 38-51.

Krassilstschik, I.M., 1888. La production industrielle des parasites vegetaux pour la destruction des insectes nuisibles. Bull. Sci. Fr. Belg. $19,461-472$.

Krieg, A., Huger, A.M., Langenbruch, G.A., Schnetter, W., 1983. Bacillus thuringiensis var. tenebrionis: a new pathotype effective against Coleoptera larvae. Z. Ang. Entomol. 96, 500-508.

Lacey, L.A., Frutos, R., Kaya, H.K., Vail, P., 2001. Insect pathogens as biological control agents: do they have a future. Biol. Control. 21, 230-248.

Lacey, L.A., Undeen, A.H., 1986. Microbial control of black flies and mosquitoes. Annu. Rev. Entomol. 31, 265-296.

LeConte, J.L., 1874. Hints for the promotion of economic entomology. Am. Assoc. Adv. Sci. 22, 11-22.

Lugger, O., 1888. Fungi which kill insects. Univ. Minn. Coll. Ag. Bull. 4, $26-41$.

McCoy, C.W., 1978. Entomopathogens in arthropod pest management programs for citrus. In: Allen, G.E., Ignoffo, C.M., Jaques, R.P. (Eds.), Microbial Control of Insect Pests: Future Strategies in Pest Management Systems. Univ. of Florida, Gainesville, FL, pp. 211 219.

McCoy, C.W., Samson, R.A., Boucias, D.G., 1988. Entomogenous fungi. In: Ignoffo, C.M., Mandava, N.B. (Eds.), Handbook of Natural Pesticides, Vol. V. Microbial Pesticides Part A. Entomogenous Protozoa and Fungi. CRC Press, Boca Raton, FL, pp. 151236.

McCoy, E.E., Glaser, R.W., 1936. Nematode culture for Japanese beetle control. N.J. Agric., 265.

McFadden, M.W., Dahlsten, D.L., Berisford, C.W., Knight, F.B., Metterhouse, W.W., 1981. Integrated pest management in China's forests. J. Forestry. 79, 714, 723-726, 779.

McGaughey, W.H., 1985. Insect resistance to the biological insecticide Bacillus thuringiensis. Science 229, 193-195.

Metchnikoff, E.A., 1880. Zur Lehre über Insektenkrankenheiten. Zool. Anz. 3, 44-47.

Metchnikoff, O., 1921. In: Life of Elie Metchnikoff, 1845-1916. Houghton Mifflin, London, p. 297.

Moscardi, F., 1999. Assessment of the application of baculoviruses for control of Lepidoptera. Annu. Rev. Entomol. 44, 257-289.

Soper, R.S., Shimazu, M., Humber, R.A., Ramos, M.E., Hajek, A.E., 1988. Isolation and characterization of Entomophaga maimaiga $\mathrm{sp}$. nov. a fungal pathogen of gypsy moth, Lymantria dispar, from Japan. J. Invertebr. Pathol. 51, 229-241.

Starnes, R.L., Liu, C.L., Marrone, P.G., 1993. History, use, and future of microbial insecticides. Am. Entomol. 39, 83-91.

Steinhaus, E.A., 1949. Principles of insect pathology. McGraw Hill Co. New York.

Steinhaus, E.A., 1956. Microbial control-the emergence of an idea. A brief history of insect pathology through the nineteenth century. Hilgardia 26, 107-160.

Steinhaus, E.A., 1957. Microbial diseases of insects. Annu. Rev. Microbiol. 11, 165-182.

Steinhaus, E.A., 1975. Disease in a minor chord. Ohio State University Press, Columbus.

Tabashnik, B.E., Cushing, N.L., Finson, N., Johnson, M.W., 1990. Field development of resistance to Bacillus thuringiensis in diamondback moth (Lepidoptera: Plutellidae). J. Econ. Entomol. 83, 1671-1676. 
Vail, P.V., Coulson, J.R., Kauffman, W.C., Dix, M.E., 2001. History of biological control programs in the United States Department of Agriculture. Am. Entomol. 27, 24-50.

Weseloh, R.M., 1998. Possibility for recent origin of the gypsy moth (Lepidoptera: Lymantriidae) fungal pathogen Entomophaga maimaiga (Zygomycetes: Entomophthorales) in North America. Environ. Entomol. 27, 171-177.
White, R.T., Dutky, S.R., 1940. Effect of introducing milky disease on populations of Japanese beetle larvae. J. Econ. Entomol. 33, 306-309. Zelazny, B., 1976. Transmission of a baculovirus in populations of Oryctes rhinoceros. J. Invertebr. Pathol. 27, 221-227.

Zelazny, B., Lolong, A., Pattang, B., 1992. Oryctes rhinoceros (Coleoptera: Scarabaeidae) populations suppressed by a baculovirus. J. Invertebr. Pathol. 59, 61-68. 